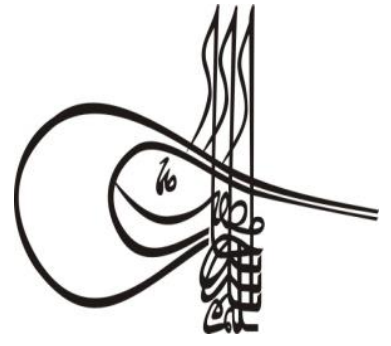

Received/Geliş: 12.04.2019

Go Report Dates/Rapor Tarihleri: Referee 1 (25.04.2019)- Referee 2 (20.05.2019)

\section{Turkigh Studies \\ Language and Literature \\ Volume 14 Issue 2, 2019, p. 677-699 \\ DOI: 10.29228/TurkishStudies. 22620 \\ ISSN: 2667-5641 \\ Skopje/MACEDONIA-Ankara/TURKEY}

Research Article / Araştırma Makalesi

Article Info/Makale Bilgisi

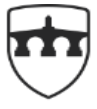

INTERNATIONAL BALKAN UNIVERSITY

EXCELLENCE FOR THE FUTURE IBU.EDU.MK

This article was checked by iThenticate.

\title{
NESÎMÎ DİVANFNDA HZ. ÂDEM BAĞLAMINDA HURÛFÎLİK PROPAGANDASI
}

\author{
Osman KUFACI
}

\begin{abstract}
öz
Nesîmî'nin, divan edebiyatının kuruluş yıllarında büyük emeği geçmiştir. Divan ve tekke edebiyatlarında önemli bir aşama olarak görülür. Yaşadığı dönemde ve vefatından sonra birçok şaire tesir etmiştir. Şiirlerine pek çok nazire yazılmış üstün bir yetenektir. Nesîmî tekke şiirini yüksek bir olgunluk derecesine ulaştırmıştır. Onun şiirleri tasavvuf şiirinin en güzel ve mükemmel örnekleri içerisinde yerini alır. Tasavvufi Türk şiirinin öncü isimlerindendir. Hallac-1 Mansur ve Fazlullah-1 Hurûfî gibi ilahi assk vadisinde yol almıştır. Maddi aşkı dile getirdiği şiirlerinin sayısı çok azdır. Bu şiirler tahminen ilahi aşkı hissetmeden önce gençlik yıllarında kaleme aldığı şiirleridir. Vahdet-i vücut tabiri şiirlerinde hiç geçmemesine rağmen vahdet-i vücut felsefesi ile ilahi aşkı etkili bir biçimde ifade eder. Vahdet-i vücut anlayışını Hurûfilikle örerek Türk edebiyatına yerleștirmiş hatta inandığı düşünce uğruna bu yolda canını feda etmiştir.

Divan şiiri çeşitli kaynaklardan beslenmiştir. Bunların arasında din önemli bir yer tutar. Ayrica dinî yorumlar ve tarikatlar da şiirde kendini gösterir. Bazı şairler Fazlullah-1 Hurûfínin inşa ettiği Hurûfílik öğretisinden oldukça istifade etmiş ve bu bağlamda zengin çağrışımlar ortaya koymuştur. Hurûfîler dinin her alanında olduğu gibi peygamberler hakkında da tevil geliştirmişlerdir. Bu sebeple Hurûfilik bakış açısıyla peygamberlerin divan şiirinde ele alınma biçimi önem arz eder. Bizzat kendisi de bu inanca candan bağlı olan Nesîmî'nin Divan'1 Hurûfilik araştırmaları için kaynak eserlerden biri durumundadır. Eserin bu perspektifle ayrica incelenmesi gerekir.
\end{abstract}

Dr. Öğr. Üyesi, Sinop Üniversitesi Fen-Edebiyat Fakültesi Türk Dili ve Edebiyatı Bölümü, E-posta: osmankufaci@hotmail.com 
Bu makale, Nesîmî Divanı'nda Hz. Âdem'le ilgili beyitlerin tespiti ve beyitlerin incelemesini kapsamaktadır. Çalışmamızda Nesîmî Divanı'nda Hz. Âdem'in Hurûfî bakış açısıyla ne şekilde ele alındığını ortaya koyduk. Hz. Âdem'le ilgili beyitlerden elde ettiğimiz bulgulardan hareketle tespitlerimizi maddeler hâlinde sıraladık. Çalışmamız, divan şiirinde Hurûfîlerin peygamberlere bakışını göstermesi ve bu yolda çeşitli sonuçlara ulaşması bakımından alandaki bu boşluğu dolduracak adımların ilkidir.

Anahtar Kelimeler: Nesîmî Divanı, Hz. Âdem, Hurûfîlik, Fazlullah1 Hurûfî, Divan Şiiri.

\title{
HURUFISM PROPAGANDA IN NESIMI'S DIVAN IN THE CONTEXT OF PROPHET ADAM
}

\begin{abstract}
Nesimi had great work in the establishment of the years of divan literature. It was an important stage in divan and Islamic monastery literature. Nesimi influenced many poets during his life and after his death. Nesimi was a superior talent whose poems replied in kind. Thus, the fame and the influence of Nesimi surpassed Azerbaijan, spread to Anatolia, Iran, and Iraq, and his Sufi poems became popular in Central Asia, and even saint legends appeared about Nesimi. Nesimi spread the philosophy of hurufism in a fearless way, faced all kinds of dangers for this reason and was killed in the end because Nesimi was a struggling intellectual who had faced every problem.

Ottoman poetry was inspired by various sources. Religion takes an important place among them. Religious interpretations and sects manifest themselves in poetry as well. Some poets drew on Hurufism doctrine founded by Fazlu 1-Lah Astar-Abadi considerably, and presented rich associations within this context. As in every area of religion, Hurufis proposed rich interpretations about the prophets. Thus, how the prophets were addressed in the Ottoman poetry with a Hurufi perspective is important. Divan by Nasimi, a fervent follower of this belief himself, is one of the reference works for Hurufism research. The book requires additional scrutiny with this perspective.

This paper seeks to identify and analyze the couplets about Adam in Nesimi Divan. In our study, we have revealed how Prophet Adam was dealt with from the Hurufism perspective in Nesimi's Divan. Starting from the findings obtained from couplets related to Adam, we have listed our findings in substances. Our work is the first of the steps that will fill this gap in the field in order to show the prophet's view of the Hurufis in Divan poetry and to reach various conclusions on this path.
\end{abstract}

\section{STRUCTURED ABSTRACT}

Hurufism was built by Fazlullah Esterabadi in 1357 or 1398 (in $758 / 800$ in Islamic Calendar). The term "huruf" means "letters" in Arabic. In this case, the term "hurufis" means those who believe in the letters. 
Hurufis shaped their own philosophies based on the ontological priority of the letters. According to the hurufis, the creation began with the sound of letters and everything in the universe had the sound. These sounds in the universe were 32 characters, which corresponded to 32 letters. 32 letters were the basis of existence. Although the non-livings and the animals got out of these sounds, only the human among the creatures, had the ability to pronounce all letters. Because the letters were based on the existence and covered the existence, they put the 28 letters of the Qur'an and the 32 letters in the speech of Fazlullah and the people who said all of them on the basis of their philosophy. Since the letters were the basis of existence, in some way, they had to appear and be observed in all manner. The whole presence was supposed to be visible in those letters. Hurufis tried to show the existence of 28 and 32 letters from the Prophets to angels, from worship to the Hereafter, from the Qur'an to the hadiths, in short, in all the things found in Islam.

The human was the second fundamental subject that philosophy of hurufism emphasized. The human, who was created as "Ahsen-i Takvim (means the dandiest creature in Islam)" (et-Tin 95/4 in Qur'an) and referred as the caliph of God with all its features, was placed on the basis of the philosophy of hurufism. The angels and other creatures did not possess the 32-letters, the word of God, and their pronunciations. In addition, the signs of the letters 28 and 32 were only seen through the letters on the human face and body. In other beings, this view was limited and not as obvious as in human beings.

Nesimi, who sang poems in Azerbaijani Turkish, was one of the most famous poets of the Azerbaijani region. However, his fame and influence spread over a wide area. Therefore, Nesimi was regarded as one of the great poets of the literature. It is not known much about his life. According to the latest research, it is stated that the principal name of the poet was Ali and the birthplace was the central Shamakhi of Shirvan and this view is generally accepted. Nesimi, who was originally Turkmen, continued his life in Baku and Shirvan with Fazlullah for a long time. He was also called as the Sayyid Nesimi or the Sayyid Imamuddin Nesimi because of the fact that Nesimi was a descendant of Prophet Hussein or because Nesimi was mentally connected to Prophet Hussein.

It was stated that Nesimi was born in 748 or 772 in the sources. According to recent research, the birth date of Nesimi is estimated as $770 / 1370$. The information about the family and environment of Nesimi is also very limited. In some sources, it is stated that Nesimi married Fazlullah's daughter. It is understood in the personal record of Ebu'l Fazl that Nesimi gave his sheik's name to the child born as a result of this marriage. It is also known that Nesimi had a brother named Shah Handan and that he was known as Shahada among the people.

No information is found in the sources about the education and study of the poet (Nesimi). It is understood from Nesimi's poems that Nesimi was fluent in Arabic and Persian as a native and that Nesimi mastered enough to write poems in those languages. However, the fact that he had a good grasp of religious sciences such as hermeneutics, Islamic law, the euphemism was observed in his poems. Nesimi is thought to have trained himself by taking special courses even if he did not take madrasa education. 
Nesimi was first among the dervishes of sheik Shibani. Then, Nesimi became one of the famous caliphs of Fazlullah Hurufi and Fazlullah's son-in-law. Nesimi played a very important role in the spread of the philosophy of hurufism. For this reason, Nesimi was sometimes called as emir and sometimes as sheik. Nesimi appointed the poet Refii, one of his followers, to organize the hurufism in Anatolia. Nesimi was interrogated due to his excessive propaganda with the power of poetry. Nesimi moved to Aleppo from Anatolia. Nesimi was executed due to his ideas during the time of Melikül-Mueyyed, in other words, Seyfuddin. There were many mysteries about Nesimi's death. The way Nesimi was killed and the date of his death also differed in the sources. Refii completed his work named Beşaretname in $811 / 1409$. Refii mentioned the death of his sheik-Nesimi in this work. Therefore, it should be accepted that Nesimi died before the date Beşaretname was completed. According to this, the date of Nesimi's death should be accepted as $807 / 1404$. Although some sources indicate that Nesimi's grave is in the village of Zerkan in the province of Shiraz, his grave is in the city of Aleppo and called Nesimi as his own name.

Nesimi had great work in the establishment of the years of divan literature. It was an important stage in divan and Islamic monastery literature. Nesimi influenced many poets during his life and after his death. Nesimi was a superior talent whose poems replied in kind. Thus, the fame and the influence of Nesimi surpassed Azerbaijan, spread to Anatolia, Iran, and Iraq, and his Sufi poems became popular in Central Asia, and even saint legends appeared about Nesimi. Nesimi spread the philosophy of hurufism in a fearless way, faced all kinds of dangers for this reason and was killed in the end because Nesimi was a struggling intellectual who had faced every problem.

Nesimi was one of the lyrical poets of the divan literature. Nesimi's enthusiastic singing, fiery style, simple and harmonious language are immediately visible in his poetry. These features made Nesimi a great and mighty poet. What made Nesimi different from other poets was that Nesimi was an enthusiastic, faithful, daring combatant, a mystic poet. Nesimi was one of the poets, who was very close to the community and folk songs were found in the poems of Nesimi. Nesimi had a simple and harmonious language. Nesimi skillfully used the sound and word repetitions in some of his poems to reinforce the meaning. Nesimi converted Turkish of that time to a beautiful poetry language. In this respect, Nesimi was really a great artist.

Nesimi expressed his love of the Prophet in most of the poems of the Divan. Besides, Nesimi treated the love of Ali, Hussein, and twelve sect leaders. The members of bektashism regarded Nesimi as one of the seven great Alawite poets, such as Fuzuli, Hatayi, Pir Sultan Abdal, Himmet, Yemini, and Virani. Nesimi quoted many verses from the Qur'an and the hadith in his poems. There was no such quotation in the poems of other poets of divan poetry and Islamic monastery poetry. In this respect, Nesimi was one of the rare poets.

The Divan of Nesimi, whom himself was bound to this faith is one of the source works for the research of hurufism. Nesimi's Divan must also be separately examined with this perspective. This paper seeks to identify and analyze the couplets about Adam in Nesimi Divan. In this 
study, it has been revealed how Prophet Adam was dealt with from the hurufism perspective in Nesimi's Divan. Starting from the findings obtained from couplets related to Adam, it has been listed the findings in substances. This work is the first of the steps that will fill the gap in the field in order to show the Prophet's view of the hurufis in divan poetry and to reach various conclusions on this path.

Keywords: Nesimi's Divan, Prophet Adam, Hurufism, Fazlullah-1 Hurufi, Divan poetry.

\section{Giriş}

\section{Nesîmî'nin Hayatı ve Edebi Kişiliği ${ }^{1}$}

Azerî Türkçesiyle şiirler söyleyen Nesîmî Azerî sahasının en tanınmış şairlerinden biridir. Bununla birlikte şöhret ve tesiri çok geniş bir alana yayılmıştır. Bu yüzden edebiyatımızın büyük şairlerinden biri olarak kabul görmektedir. Hayatı hakkında fazla bir bilgiye sahip değiliz. Son araştırmalara göre şairin asıl adı Ali olup doğum yeri Şirvan'ın merkezi Şamahı olarak gösterilmiş ve çoğunlukla bu görüş kabul görmüştür. Kaynaklarda İmâüddîn, Müslihüddîn, Nesîmüddîn unvanları ile zikredildiğine dair ibareler yer alır. Aslen Türkmen olan Nesîmî uzun süre Fazlullah'ın yanında Bakü ve Şirvan'da hayatını sürdürmüş̧ür. Hz. Hüseyin'in soyundan geldiği veya manen ona bağlı bulunması sebebiyle de Seyyid Nesîmî veya Seyyid İmâmüddîn Nesîmî olarak zikredilir. Şairin künyesi şiirinde ifade ettiği üzere Ebu'l-Fazl'dır.

Nesîmî’nin kaynaklarda 748 veya 772 yllında doğduğu belirtilir. Son araştırmalara göre Nesîmî'nin doğum yılı 770/1370 olarak tahmin edilmektedir. Ailesi ve çevresi hakkında edindiğimiz bilgiler de oldukça sınırlıdır. Bazı kaynaklarda mürşidi Fazlullah'ın kızı ile evlendiği ifade edilir. Bu evlilikten dünyaya gelen çocuğuna ise şeyhinin adını verdiğini künyesi Ebu'l-Fazl'dan anlamaktayız. Ayrıca Şah Handan adında bir kardeşinin olduğunu, bu kişinin halk arasında "Şahanda" adıyla tanındığını biliyoruz.

Şairin eğitimi ve öğretimi hakkında da kaynaklarda herhangi bir bilgiye rastlanmaz. Şiirlerinden Arapça ve Farsçayı ana dili gibi bildiği ve o dillere şiir yazacak kadar hâkim olduğu anlaşılmaktadır. Bununla birlikte tefsir, fikıh, kelam gibi dinî ilimlere de iyi derecede vakıf olduğu şiirlerinde görülür. Medrese eğitimi almasa bile Nesîmî’nin özel dersler alarak kendisini yetiştirdiği düşünülmektedir.

İlk önce Şeyh-i Şiblî’nin dervişleri arasındadır. Sonraları ise Fazlullah-1 Hurûfînin meşhur halifelerinden biri ve damadı olmuştur. Hurûfîlik felsefesinin yayılmasında çok önemli bir rol oynamıştır. Bu yüzden bazen Emîr bazen de Şeyh unvanlarıyla anılmıştır. Nesîmî, müritlerinden olan şair Refî' '̂̀'yi Hurûfíliği Anadolu'da yayması için görevlendirmiştir. Aşırı bir şekilde ve şairlik gücüyle propaganda yapması sorgulanmasına neden oldu. Anadolu'dan sonra Halep'e gitti. Melikü'l-Müeyyed diğer bir ifadeyle Müeyyedîlerden Seyfüddîn zamanında fikirleri sebebiyle idam edildi. Ölümü hakkında birçok menkıbe teşekkül etti. Öldürülüş şekli ve ölüm y1lı da kaynaklarda farklılık gösterir. Farklı kaynaklar 807/1404, 820/1433, 837/1433, 840/1436 yıllarını ölüm yılı olarak gösterir. Refí'î, Beşâretnâme isimli eserini 811/1409'da tamamlamıștır. Bu eserde Refî'î, șeyhi Nesîmî'nin ölümünden bahseder. Bu yüzden Nesîmî'nin bu yıldan önce öldügü kabul edilmelidir. Buna göre Nesîmî'nin ölüm yılını 807/1404 olarak kabul etmek gerekmektedir. Bazı kaynaklar kabrinin Şiraz'ın Zerkan köyünde olduğunu belirtse de kabri Halep’te kendi adıyla anılan bir tekkede bulunmaktadır.

\footnotetext{
${ }^{1}$ Nesîmî’nin hayatı ve edebi kişiliği için şu kaynaklardan yararlanılmıştır: Ayan, Hüseyin (2002). Nesîmî, Hayatı, Edebî Kişiliği, Eserleri ve Türkçe Divanının Tenkitli Metni I, Ankara: TDK Yay, s. 1-104; Bilgin, Azmi (2007). "Nesîmî”, DİA, C. 33, İstanbul: Türkiye Diyanet Vakfi Yay., s. 3-5; Karabey, Turgut (2017). Karabey, Turgut (2017). Nesimi -Hayatı, sanatı, eserleri, Bazı Şiirlerinin Açıklamaları, Ankara: Akçağ Yay., s. 41-124.
} 
Divan edebiyatının kuruluş yıllarında büyük emeği geçmiştir. Divan ve tekke edebiyatlarında önemli bir aşama olarak görülür. Yaşadığı dönemde ve vefatından sonra birçok şaire tesir etmiştir. Şiirlerine pek çok nazire yazılmış üstün bir yetenektir. Hüseyin Ayan, onun şiirlerini Fazlullah-1 Hurûfî'ye intisap etmeden önce ve sonra olmak üzere iki dönemde incelemiştir. Nesîmî, Fazlullah'a intisap etmeden önceki şiirlerinde maddi aşk, şarap, tabiat, dünyanın vefasızlı̆̆ı, faniliği, Hz. Ali, Ehl-i Beyt ve On İki İmam sevgisi gibi konuları işlemiştir. Şiirlerinde bilhassa Hz. Muhammed, Hz. Ali, Ehli Beyt ve On İki İmam'a karşı derin bir bağlılık ve sevgi vardır. İlk dönem şiirlerinde hikmetli söz söyleme ve nasihat etme arzusu hâkimdir. Bundan dolayı şiirlerinde didaktik üslup hâkimdir. $\mathrm{Bu}$ dönemki şiirlerinde Ahmed-i Yesevî ve Mevlânâ Celâleddîn-i Rûmî’nin etkisi açıktır.

Fazlullah-1 Hurûfî’ye intisap ettikten sonraki ikinci dönemde iç dünyasında büyük değişiklik olur. Bu durumu yer yer şiirlerinde beyan eder. Fazlullah ona hidayet kapısını açar, huzura kavuşur. Hurûfîlik sistemindeki harfler dünyasına giren Nesîmî, Hurûfîlik felsefesini büyük şevk ve heyecanla şiirlerinde işleyerek başkalarına da telkin etmeye başlar. Bu şekilde Fazlullah'ın dervişleri ve halifeleri arasındaki yerini alır. Nesîmî, bu dönemki şiirlerinde ilahi aşk1, insan sevgisini işleyerek vahdet-i vücut düşüncesini terennüm eder. Mücadeleci bir kişiliğe sahip mutasavvıf bir şair olarak edebiyat sahnesinde önemli bir rol icra eder. Böylece onun şöhreti ve etkisi Azerbaycan'ı aşar, Anadolu, İran ve Irak’a kadar yayılır; yazdığı tasavvufi şiirler Orta Asya'da rağbet görür, hatta hakkında menkıbeler anlatılır. Nesîmî, Hurûfîlik felsefesini korkusuz bir şekilde yaymış, bu uğurda her türlü tehlikeyi göze almış ve her sıkıntıya göğüs germiș mücadeleci bir arif olduğundan en sonunda öldürülmüştür. Bununla birlikte Usluer, makalesinde Nesîmî'nin şiirlerini iki dönem olarak değerlendirmenin yanlışlığını dile getirir. ${ }^{2}$

Nesîmî tekke şiirini yüksek bir olgunluk derecesine ulaştırmıştır. Onun şiirleri tasavvuf şiirinin en güzel ve mükemmel örnekleri içerisinde yerini alır. Tasavvufi Türk şiirinin öncü isimlerindendir. Hallac-1 Mansur ve Fazlullah-1 Hurûfî gibi ilahi aşk vadisinde yol almıştır. Maddi aşkı dile getirdiği şiirlerinin sayısı çok azdır. Bu şiirler tahminen ilahi aşkı hissetmeden önce gençlik yıllarında kaleme aldığ 1 şiirleridir. Vahdet-i vücut tabiri şiirlerinde hiç geçmemesine rağmen vahdet-i vücut felsefesi ile ilahi aşk1 etkili bir biçimde ifade eder. Vahdet-i vücut anlayışını Hurûfîlikle örerek Türk edebiyatına yerleştirmiş hatta inandığ düşünce uğruna bu yolda canını feda etmiştir. Şiirlerinde Hallac-1 Mansur'un adını ve onun ölümüne sebep olduğu ileri sürülen "Ene'l-Hak" sözünü çokça kullanır. Bu durum, onun Hallac-1 Mansur'un düşüncelerine bağlı olduğunu gösterir. Nitekim ölümü Hallac-1 Mansur'un ölümü gibi olmuştur. Aynı şekilde şiirlerinde bazen adını söyleyerek bazen de dolaylı olarak mürşidi Fazlullah1 Hurûfi’’yi aşırı bir şekilde yüceltir.

Edebiyatımızın lirik şairlerinden birisidir. Heyecanlı edası ve ateşli söyleyişi, sade ve ahenkli dili şiirlerinde hemen göze çarpar. Bu özellikleri onu büyük ve kudretli bir şair hâline getirmiștir. Onu diğer şairlerden farklı kılan yönü coşkun, inançlı, pervasız ve mücadeleci bir mutasavvıf şair olmasıdır. Şiirlerinde halk söyleyişleri sıkça görüldüğü için Nesîmî, halka çok yaklaşan şairlerden biridir. Sade ve ahenkli bir dile sahiptir. Bazı şiirlerinde ses ve söz tekrarları ustaca yer bulmuştur. Bu tarz şiirlerinde ses ve söz tekrarlarını anlamı pekiştirecek şekilde kullanmıştır. Dönemin Türkçesini güzel bir şiir dili hâline getirmiştir. Bu bakımdan gerçekten büyük bir sanatkârdır.

Özer Şenödeyici, Divan'daki şiirleri farklı duyarlılıklar çerçevesinde değerlendirdiğinde Nesîmî'nin şiirlerini aşağıdaki başlıklar çerçevesinde ele almıştır: 1. Așk ve güzellik konulu șiirler, 1.1. Beşerî aşk konulu şiirler, 1.2. İlahî aşk konulu şiirler, 1.3. Hurûfîyâne aşk konulu şiirler, 2. Didaktik şiirler, 2.1. Doğrudan tasavvuf terimleri ile oluşturulmuş şiirler, 2.2. Şî̂-Alevi inanışını konu alan şiirler, 2.3. Hurûfî tevillerini konu alan didaktik şiirler. ${ }^{3}$

\footnotetext{
${ }^{2}$ Usluer, Fatih (2009). "Nesîmî Şiirleri Şerhlerinde Yapılan Yanlışlıklar”, Turkish Studies, Vol 5/2 (Winter), s. 1080.

${ }^{3}$ Şenödeyici, Özer (2015). Nesîmî ve Hurûfîlik Kitabı. İstanbul: Kesit Yay, s. 60-64.
} 
Nesîmî, şiirlerinde Hurûfîlik inancının akidelerini olabildiğine işlemiştir. Hurûfîliğin harf oyunlarına dayanan cephesini değil, daha çok bu felsefenin heyecan ve düşünce tarafını irdelemiştir. Bununla birlikte bazı şiirlerinde Hurûfîliğin harf ve sayı olgusuna yer vermiştir.

Divan'daki şiirlerin büyük bir kısmında Hz. Peygamber sevgisini dile getirmiştir. Bunun yanı sıra Hz. Ali, Hz. Hüseyin ve On İki İmam sevgisini işlemiştir. Bektaşiler, onu Fuzulî, Hatâyî, Pir Sultan Abdal, Himmet, Yemînî ve Virânî gibi yedi büyük Alevî şairden biri olarak görür. Nesîmî, şiirlerinde Kur'an'ın ayetlerinden ve hadis-i şeriflerden pek çok iktibas yapmıştır. Diğer divan şiiri ve tekke şiiri şairlerinde bu kadar iktibasa rastlanmaz. Bu bakımdan Nesîmî bu hususta farklı davranmıştır.

Nesîmî’nin, divan şiirinde (Çağatay, Azerî ve Özbek Türkçesi vs. edebiyatlarında) ve halk edebiyatında kendi döneminde ve vefatından sonra birç̧ok şair üzerinde etkisi olmuştur. Bu takipler arasında Kayserili Temennâyî, Karaferyeli Hasan, Rûmî, Hüseynî, Yenice-i Vardarlı Usûlî, Nebâtî, Bağdadlı Tarzî, Bosnalı Vahdetî, Tebrîzli Penâhî, Muhîtî 15. yüzyıl sonralarıyla 16. yüzyılda Türkiye'de yetişen Nesîmî takipçisi Hurûfî şairlerin en tanınmışlarıdır. Düşünce tarzı ve üslubunu taklit eden ve ona nazireler yazan hatta aynı mahlası kullanan birçok şair bulunmaktadır. Adeta "Nesîmî ekolü" diyebileceğimiz bir ekol ortaya çıkmıştır. Nesîmî, birçok şairin şiirine nazireler yazdığı gibi onun şiirine de birçok şair nazire kaleme almıştır. Nesîmî'nin Türkçe Divan ve Farsça Divan'ı bulunmaktadır. Ayrıca Türkçe kaleme aldığı Mukaddimetü'l-Hakâyık adlı bir eseri daha vardır. Bu eser, mensur bir eserdir. Fazlullah'ın Câvidân-nâme'si esas alınarak yazılmıştır.

\section{Hurûfîlik}

Hurûfîlik, Fazlullah Esterabâdî tarafından 758/1357 veya 800/1398'de inşa edilmiştir. Hurûf kelimesi Arapçada "harfler" anlamına gelmektedir. O hâlde Hurûfî de harflere mensup olanlar, harfçiler manasını kazanır. Bazı yazarlar, Hurûfîlerin içerisindeki zanaatkârların çokluğundan hareket ederek Hurûfî sözcüğünün meslek anlamındaki "hurfe" kelimesinden türediğini ileri sürmüşlerdir. Fakat bu dilbilgisi bakımından doğru değildir. Diğer taraftan Hurûfîliğin bir zanaatkârlar topluluğu olarak görülmesi de yanlıştır, çünkü Fazlullah'ın öğrencileri arasında belirli meslek gruplarını temsil eden kişilerin yanında birçok âlim, devlet adamı ve asker de bulunmaktaydı. ${ }^{4}$

Hurûfîler kendi felsefelerini, harflerin ontolojik önceliğinden hareketle şekillendirirler. Hurûfîlere göre yaratılış harflerden oluşan sesle (kün) başlamıştır. Evrendeki her şeyde ses bulunmaktadır. Evrendeki bu sesler 32 tanedir ve bu da 32 harfe tekabül etmektedir. 32 harf varlığın temeli durumundadır. Cansızlar ve hayvanlar bu sesleri çıkarsa da yaratılmışlar içerisinde sadece insan harflerin hepsini telaffuz edebilme kabiliyetine sahiptir. Hurûfîler harfleri; harflerin varlığın temelinde olması, varlığı kapsamasından dolayı, Kur'an'ın 28 harfi ve Fazlullah'ın nutkundan gelen 32 harfi ve bunların tamamını söyleyen insanı, felsefelerinin temeline koymuşlardır. Harfler varlığın temeli olduğuna göre, bir şekilde bütün mevcudatta görünüp müşahede edilmelidir. Bütün mevcudat bu harflerde görünebilmelidir. Kur'an'da geçen "Ne kuru ne yaş, hiçbir şey yoktur ki, o her şeyi açıklayan Kitap'ta bulunmasın." (el-En'âm 6/59), "Biz her şeyi açık bir kitapta (Levh-i Mahfuz'da) sayıp tespit etmişizdir." (Yâsîn 36/12) ayetleri her şeyin 28 harften meydana gelen Kur'an'da olduğu hakikatini ifade etmektedir. Ama ayetlerde dile getirilen "Kitap"tan kastedilen Kur'an-1 Kerim değildir. Çünkü Kur'an'da p, ç, j, g harfleri yer almaz. Kitap'tan kastolunan 32 harften oluşan Levh-i Mahfuz'dur. Varlığın temelinde 28 ve 32 ilahî harf bulunduğundan Hurûfîler; peygamberlerden meleklere, ibadetlerden ahirete, Kur'an'dan hadislere kısacası İslam içerisinde bulunan her şeyde 28 ve 32 harfin varlığını göstermeye çalışmışlardır.

\footnotetext{
${ }^{4}$ Hurufi göndermeler için çoğunlukla, aksi belirtilmediği sürece, Fatih Usluer'in "Hurufilik, İlk Elden Kaynaklarla Doğuşundan İtibaren (2009)" adlı eserinden istifade edilmiştir.
} 
Hurûfîler "Benden bir şey duyduğunuzda, onu Allah'ın kelamıyla karşılaştırın..." hadisini Hz. Muhammed'in, Müslümanları gerçekleri 28 ve 32 harfte aramaya teşvik etmesi olarak algılamışlardır. Elbette Hz. Peygamber'in burada söylemediği hâlde kendisine atfedilebilecek sözleri ayırmak için hadislerin Kur'an'la karşılaştırılmasını emretmesi söz konusudur. Hurûfîler buradaki "Allah'ın kelamı"nı 28 ve 32 harfle tevil etmiş, hatta emri genişletip âlemdeki her şeyi 28 ve 32'yle kıyaslamıştır. Diğer bir ifadeyle varlık âleminde bulunan 28 ve 32 harfin alametlerini göstermeye çalışmıştır.

Hurûfîler, harfleri asla kehanet, büyü, tılsım, muska gibi okült ilimlerde kullanma yoluna gitmemişlerdir. İktidarı ele geçirme, dini tahrif etme, bir mezhebin taraftarlığını yapma gibi bir amaçları yoktur. Maksatları sadece batınında ve tüm dinsel amellerdeki 28 ve 32 harfin alametlerini göstermektir. Çünkü bu sayede iman ve ibadetler bir anlam ifade edecektir.

Hurûfî felsefesinin harflerden sonra vurgu yaptığı ikinci temel konu insandır. "Ahsen-i Takvîm" (et-Tîn 95:4) üzerine yaratılmış, Allah'ın yeryüzündeki halifesi insan, daha sonra bütün özellikleriyle Hurûfî felsefesinin temelinde konumlanır. Allah'ın kelamı olan 32 harfe ve bunların telaffuzuna melekler ve diğer yaratıklar sahip değildir. Ayrıca 28 ve 32 harfin alametleri sadece insanın yüzünde ve vücudunda harfler aracılığıyla temaşa edilir. Diğer varlıklarda bu görünüş sınırlıdır ve insandaki gibi apaçık değildir.

Hurûfîler insan vücudunu harfler üzerinden çözümlemeye çalışmışlardır. "Nefislerinizi hesaba çekilmeden önce hesaba çekiniz." (Meclisî, C. 27: 73) hadisinden hareket eden Hurûfîler insan vücudunda harflerin, başka bir ifadeyle Allah'ın kelamının alametlerinin bulunduğu fikrine varmışlardır. Bu hadis Ferişteoğlu tarafından "Varlığınızın (vücudunuzun) hesabını yapın." şeklinde yorumlanmıştır. Hadisin ifade ettiği hesap, insan hilkatinde 28 ve 32 harfin görülmesidir. Bu şekilde "Biz onlara hem evrende hem kendi nefislerindeki ayetlerimizi göstereceğiz." (Fussilet 41/53) ayetinde nefislerdeki Allah'ın ayetleri; diğer bir ayette (er-Rûm 30/30) Allah'ın fitratı üzerine insanın fitratının yaratılması gösterilmiş olur.

Hurûfîlere göre ilahî kelimelerin kâmilen zuhur ettiği yer yüzdür. Yüzde bulunan duyu organlarının taksimi; 2 göz 2 kulak, 2 burun ve 1 ağız olarak 7 tanedir. Her biri dörder unsurdan oluşması hasebiyle 28 ilahî kelimeye işaret eder. Dilin altındaki istiva hattı hesaba katıldığında 8 kısım ortaya çıkar. Ayrıca 4 unsur üzerinden hesaplandığında 32 ilahî kelime hizasında 32 alamet elde edilmektedir. Hurûfîlerce yüz, aynı zamanda levh-i mahfuz olarak kabul edilmektedir. Çünkü kâinatın hükümleri, ezel ve ebeddeki tüm bilgiler yüzde tasvir edilmiştir. Yüz, kâinat kitabının bir nüshasıdır. Yüz, Kur'an-1 Kerim gibi 28 harfin alameti üzerine olduğu için Cebrail, Kur'an-1 Kerim'i oradan getirmiştir. İnsanın yüzü de o fitrat üzerine yaratılmıştır. İnsan yüzünde Allah'ın kelamı 28 ve 32 alametle zahirdir. Harfler, Allah'ın kelamı olarak Allah'ı ifade eder. Allah'tan ayrı düşünülmezler. Hurûfîler harflerin mevcudiyetini yaratılmış her şeyde ve kendi varlıklarında (insan varlığında) görürler. Bu şekilde Allah'1 kendilerinde müşahede ettiklerine inanırlar.

\section{Nesîmî Divanı'nda Hz. Âdem ${ }^{5}$}

İnsanların atası olan Hz. Âdem, Allah'ın yarattı̆̆ı ilk insan ve ilk peygamberdir. Allah, onu topraktan (kuru çamurdan şekillendirilmiş balçıktan) yaratmıştır. Onu düzenleyip ruhundan üflemiştir. Eşi Havva'yı ise Hz. Âdem'e dostluk etmesi için onun kaburga kemiğinden meydana getirmiştir.

\footnotetext{
${ }^{5}$ Bu makaledeki şiir numaraları Hüseyin Ayan'ın Nesîmî, Hayatı, Edebî Kişiliği, Eserleri ve Türkçe Divanının Tenkitli Metni 1-2 (TDK Yay., Ankara 2002) adlı çalışması esas alınarak verilmiştir. Kısaltmalar: d. (Doğum yılı), ö. (Ölüm yılı), Yay. (yayın(lar)1), G. (Gazel), Mes. (Mesnevi), Müs. (Müstezat) T. (Tuyuğ), Tb. (Terkîb-i bent). Makaleye alınan şiirlerin künyesi; nazım şeklinin kısaltması, nazım şeklinin divandaki numarası/beyit numarası şeklinde gösterilmiştir. Örneğin, G. 326/13 ibaresi, Nesîmî Divanı 326. gazelin 13. beytini ifade etmektedir.
} 
Meleklere öğretilmeyen bütün varlıkların (eşyanın) isimleri Allah tarafından öğretilmişti (elBakara 2/31-33). Allah, onu yarattıktan sonra, meleklere ona secde etmelerini emretmiş, bütün melekler secde ettiği hâlde sadece şeytan kibirlenerek kendinin ateşten, Hz. Âdem'in ise topraktan yaratıldığını söyleyerek secde etmemiştir (el-Bakara 2/34). Allah, bu yüzden şeytanı cennetten ebedî olarak kovdu. Bunun üzerine şeytan Allah'tan insanların dirileceği güne kadar mühlet istedi. Allah da şeytana mühlet verdi. Şeytan da kıyamete kadar insanları saptırmak için kendini görevli addetti. Allah, Hz. Âdem ve Havva'ya cennette bulunan bir ağacın meyvesinden yememelerini emretti. Onlar, şeytanın kandırmasıyla bu ağacın meyvesinden yedi ve bunun neticesinde Allah tarafından cennetten çıkarılıp dünyada ikamete zorunlu kılındı. Bütün insanlar Hz. Âdem ile Havva'dan türediler.

Hurûfîlere ait eserlerde “Âdem” isminin ilk peygamber Hz. Âdem'i mi Fazlullah-1 Hurûfî’yi mi ifade ettiği çoğu kez belli değildir. Ayrıca bu isim "insan" anlamına da gelmektedir. Bu anlam katmanları dolayısıyla Hurûfîlere ait şiirler çok farklı şekillerde yorumlanabilir. Hurûfîler Hz. Âdem'i kendi inanç perspektifleri açısından ele almışlar ve yorumlar geliştirmişlerdir. Böylece, müntesipleri onların şiirlerini okurken kendi felsefeleri bağlamında bir şey anlarken, sıradan bir insan daha farklı bir şey anlayacaktır. Nesîmî Divanı'nda Hz. Âdem bağlamında Hurûfîlikle ilgili düşünceler; şeytan, secde, Âdem 'in yüzü, Âdem 'in Tanrı mazharl olmasl, ayetlerle Âdem, "Esmâ-i Kül”, Âdem ve Hz. Muhammed, Âdem ve vahdet-i vücut, Âdem ve diğer peygamberler, Hz. Âdem'in cennetten çıkarılması, Âdem ve “Küntü Kenz", Hz. Âdem 'in yaratılması ve önemi gibi başlıklar altında ele alındı.

\section{Seytan}

Divan'da Hz. Âdem ile ilgili beyitlerde şeytanın ona secde etmemesi hadisesi bilhassa konu edilmektedir. Muhatabını, daha doğrusu Hurûfîlik felsefesine karşı çıkan kişiyi, iblis olarak niteleyen Nesîmî, muhatabından eğer şeytan değilse Âdem'i anlamasını/tanımasını/bilmesini beklemektedir. Burada Âdem; Hz. Âdem, Fazlullah-1 Hurûfî ve "insan” anlamına gelecek şekilde kullanılmıştır:

İy Ḥaḳdan rrah olan ' azāzìl

Ger dīv degülseñ Ādemi bil (Mes. 1/24)

"Ey Allah’tan uzak olan İblis, eğer şeytan değilsen Hz. Âdem’i (insanı) anla.”

“Sahib-i zaman” olarak görülen Fazlullah'ın Hz. Âdem'in sırrı olduğu dile getirilmektedir:

Nefḥ-i 'i isā ölü dilidür hemān

Ādemüñ sırrıdur ol șāḥib-zemān (Mes. 3/148)

“O zamanın sahibi (Fazlullah), Hz. Âdem'in sırrıdır. Hz. İsa nefesi hemen ölü diriltir.”

“Allah, Âdem'i Rahman sureti üzerine yarattı.” (Kütüb-i Sitte, C. 10: 288) ya da “Allah, Âdem'i kendi sureti üzerine yarattı." (İhsâî, C. 1: 53) rivayetleri Hz. Peygamber'in hadisleri arasında gösterilmektedir. Allah'ın sureti üzerine yaratılmasına rağmen insanın öldürülmesini vacip kabul eden anlayıșta bir zıtlık mevcuttur. Bu zıtlığa Fazlullah açıklık getirmiştir. Yukarıda zikredilen hadisteki "suret"in zuhuru, mananın ortaya çıkmasıdır. Eğer o yüz, kastedilen manaya ulaşamıyorsa, onun olmaması daha iyi bir hâldir. İkinci olarak da katli vacip olan insanlar, suretlerinden hakka yol bulamamış olanlardır. Bunların katledilmesi uygundur, ta ki başkalarının da yoldan sapmasına sebep olmasınlar. Bu tarz insan iblis gibidir; çünkü o da Hz. Âdem'in suretine secde etmemiștir. İlgili beyitlerde Âdem'e secde etmeyenlerin şeytan olarak yorumlanması bu sebepledir. Meleklerin Hz. Âdem'e secde etmeleri ile ilgili “üscûdu” ifadesi Kur'an'da (el-Bakara 2/34, el-A'râf 7/11, el-İsrâ 17/61, el-Kehf 18/50, Tâ hâ 20/116) surelerinde geçer. Kur'an ayetine atıfta bulunulan beyit yukarıdaki bilgiler bağlamında değerlendirilmelidir: 
Çün üscüdü buyurdı Ādem ḥaḳında Ḥaḳ gel

Ḥaḳkuñ huțābın işit ḳıl secde olma şeyțān (G. 326/13)

“Allah, Hz. Âdem hakkında secde et buyurduğu için gel Allah'ın hitabını işit, (ona) secde edip şeytan olma."

Secde edimi, Âdem'in yüzü makamı konumunda olan Kâbe'ye yönelilerek yapılır. Namazdaki secdeler de Âdem'in vechindeki hatlar adedindedir. İnsanların yüzleri daima Kâbe'ye çevrilir. Peygamberler ve melekler de yüzlerini Kâbe'ye yani Âdem'e dönerek secde eylemini gerçekleştirmişlerdir. Hurûfîlere göre Âdem'e secde etme emri sadece meleklerle ve belirli bir zamanla sınırlı değildir. Allah'tan gelen emir üzerine Âdem'e (Kâbe/insanın yüzüne) secde etmeyenler her zaman şeytan olarak görülmüştür:

Zerḳ ehlidür gerçek şaḳi kim țutmamış Ḥaḳ sözini

İtmedi secde Ādeme Ḥaḳdan elen şeyțān budur (G. 54/5)

“Gerçek isyankâr Allah'ın sözünü tutmayan mürailerdir. Allah’tan gelen emir üzerine Âdem'e secde etmeyen şeytan budur."

Şeytan, Allah'ın Âdem'e secde etme emrine uymamış ve şöyle demiştir: "Ben, ondan hayırlıyım; beni ateşten yarattın, onu çamurdan yarattın." (el-A'râf 7/12). Hz. Peygamber Allah'tan başkasına secde edenin kâfir olacağını bir hadisinde dile getirir. Hurûfîler şeytanın Âdem'e secde etmeyişini, hatların bilgisine ulaşmaması sebebine bağlamışlardır. Çünkü Âdem'in hatlarını ve bunların hakikatini bilseydi, bu emre uymuş olacaktı. Yani şeytan Allah'tan başka varlığın olmadığını bilmediği için de secde etmemiştir. Aşağıdaki beyit, bu bilgilerle kompoze edilmiştir:

Ādemem hem Ādeme ḳıldum sücūd ez-emr-i Ḥaḳ

Dutmadı ol emri şeyțān-1 la ìn ü oldı māt (G. 26/11) oldu."

“İnsanım hem insana Allah'ın emri ile secde ettim. O emri kovulmuş şeytan tutmadı ve mat

Aşağıdaki beyitte Hurûfîlik inancı doğrultusunda, yukarıda izah ettiğimiz bilgiler bağlamında, Âdem'in önemine işaret edilmiştir:

Yil ü șu țoprag் u od adı nedendür Ādem

Aña secde ne içün İblīse inkār nedür (G. 102/10)

"Rüzgâr, su, toprak ve ateşin adı niçin Âdem'dir. Ona niçin secde gerekir ve İblis'in bunu inkâr etmesinin sebebi nedir?"

Hz. Âdem'in 28 ve 32 ilahi kelime vasıtasıyla Allah'ın mazharı olması, şeytanın bu sırrı bilmesine rağmen ona secde etmemesi sebebiyle sonsuza kadar matemde olacağ 1 Hurûfîlik inanc1 bağlamında ifade edilir:

Ḥaḳ Te $e^{c}$ àlā varlı̀gı Ādemdedür

Ev anuñdur ol bu evde demdedür

Bildi şeyțān bu sırrı gamdadur

Ol sebebden ta ebed mātemdedür (T. 56)

"Hak Teala'nın varlığı Âdem'dedir. Ev onundur ve o bu evde nefestedir. Şeytan bu sırrı bildi ve gamdadır. O sebepten sonsuza kadar yastadır." 
Eşya, mülkün sahibi olan Allah'ın kelamının mazharıdır. Mülkü sahibinden, sahibini mülkünden ayrı düşünmenin imkânı yoktur. Eşyanın hakikati Hak'tır. Eşyayı, Tanrı'nın aynısı bilmek gerekir. Kurtuluşa ermek isteyen insanın, mevcudatın tüm zahiri suretlerini, Allah'ın kadîm sıfatını bilmesi gerekir. Mevcudatın batınını da Hak bilmesi gerekir; çünkü Hakk'ın zatının hakikatinden başka varlık yoktur. Bu bağlamda batı ve doğuda konuşan Hak'tır. Hak ortaya çıkmıştır, onu görmeyen ve Âdem'i Hak bilmeyen şeytan olmuştur:

Mag̉rib ü maşrıḳda Ḥaḳdur söyleyen

Huanı bir 'āşı̣ bugün Ḥaḳ isteyen

Ḥaḳ ' 1yān oldı vü Ḥaḳkı görmeyen

Oldı şeyțān Ādemi Ḥaḳ bilmeyen (T. 251)

"Batı ve Doğu'da konuşan Hak’tır. Bugün Hakk'1 isteyen âşık hani? Hak ortaya çıktı ve Hakk1 görmeyen ve Âdem'i Hak/layıkıyla bilmeyen şeytan oldu."

\section{Secde}

“Allah, Âdem’i Rahman sureti üzerine yaratt1.” (Kütüb-i Sitte, C. 10: 288) şeklinde nakledilen bir hadisle ilgili olarak Hurûfîler çeşitli yorumlar yapmışlardır. Bu hadis bağlamında Âdem, Allah'ın yeryüzündeki halifesi, temsilcisi, kâim-makamı; Allah'ın sıfatı olarak da zat-1 ilahiden ayrılamayacak şekilde düşünülmüştür. Aşağıdaki beyitte Allah'ın Âdem'de (Hz. Âdem/Fazlullah/insan) tecelli ettiğini söyleyen Nesîmî, meleklerin Hz. Âdem'e secde etme hadisesine de atıfta bulunur. Hurûfîlere göre Âdem'in mescûd (secde edilen) olmasının sebebi, onun Allah'ın sureti üzerine yaratılmış olmasıdır. Âdem'in vechinde ve vücudunda, Allah'in sıfatı olan ilahi kelimelerin alametleri zuhur ettiğinden de kendisine secde edilmiştir, denilebilir:

Ādemüñ șuretine secde ḳlanlar ki seni

Göricek șūret-i raḥmān didiler gerçek imiş (G. 201/4)

“İnsanın yüzüne secde edenler seni görünce Rahman'ın yüzü dediler. Hakikat imiş.”

Hurûfîler, insanın Tanrı mazharı olduğunu dile getirirler ve Tanrı'yı kendi şahıslarında müşahede ederler. Allah'ın Âdem'de tecelli ettiğinin ifade edildiği beyitte muhataptan Âdem'e secde etmesi istenmektedir:

Ādemde tecellī ḳıldı Allāh

Ḳ1l Ādeme secde olma güm-rāh (Mes. 1/24)

"Allah, Hz. Âdem'de tecelli etti. Yolunu şaşırma da Âdem'e secde et."

"Sırr-1 tevĥ̂d"den kasit, Allah'ın Âdem'de tecelli etmesidir. Burada Hz. Âdem'e Şeytan'ın secde etmemesi hadisesine vurgu yapılmakla birlikte, Hurûfî muarızlarının ve Âdem'e/insana/Fazlullah'a secde etmeyenlerin/tazimde bulunmayanların şeytan olarak vasıflandırılması da söz konusudur:

Sirr-1 tevhīide irmedi münkir

Ādeme secde ḳılmadı şeyțān (G. 327/8)

"İnkâr eden tevhid sırrına ulaşmadı. Şeytan Âdem'e secde etmedi."

Meleklerin Hz. Âdem'e secde etme hadisesini bahis konusu eden Nesîmî, muhatabına: "Yüzümüzü görmek istiyorsan secde izlerini bul." der. Bu beyitte de Hurûfillerin insan yüzünü Tanrı'nın tecelligahı olarak görmesi anlayışı yer almaktadır: 
Secde idenler melekdür Ādeme iy ādemī

Secde āsāarını bul ta göresen sīmāmuzı (G. 438/11)

"Ey insanoğlu! Âdem'e secde edenler melektir/melek gibidir.. Yüzümüzü görmek istiyorsan o secdenin izlerini bulmalısın."

Âdem'e secde edilmesinin sebebi, yukarıda temas olunduğu gibi, onun Allah'ın sureti üzerine yaratılmasıdır. Âdem'in yüzünde ve vücudunda Allah'ın sıfatı olan ilahi kelimelerin alametleri göründüğünden kendisine secde edilmiştir. Allah'ın kelamı olan harfler, onu ifade eder ve ondan ayrılmazlar. Hurûfîler harflerin varlığını tüm mevcudatta görmüşlerdir. Harflerin zuhurunu kendi varlıklarında (insan varlığında) görmek suretiyle Allah'ı kendilerinde müşahede ederler. Bu da Hz. Âdem'e talîm edilen esma-i küldür. Ayrıca 28 ilahi harf, varlığın esası olup Allah'ın zatından ayrılmamaktadır. Nesîmî; topraktan yaratılan Âdem/Fazlullah'1n Allah'ın sıfatı ve zatı olmasaydı meleklerin (ona) secde etmeyeceği ve feleklerin üstünde dönmeyeceği iddiasındadır:

Eger żāt u șıfât-1 Ḥaḳ degüldür Ādem-i huākī

Melekler sācid olmazdı felekler ḩākine gerdān (G. 311/12)

"Eğer topraktan yaratılan Âdem Allah'ın sıfatı ve zatı değilse melekler (ona) secde etmez, felekler toprağına dönmezdi."

\section{3. Âdem'in Yüzü}

Ezelde ve ebeddeki bütün bilgiler, kâinatın hükümleri, yüzde tasvir edildiği için Hurûfîler, insan yüzünü aynı zamanda levh-i mahfuz olarak kabul ederler. İnsan yüzü, kâinat kitabının bir nüshasıdır. Yüz, Kuran gibi 28 harfin alameti üzerine olduğu için Cebrail, Kur'an-1 Kerim'i oradan getirmiştir. İnsan yüzü o fitrat üzerine halk olunmuştur. Bunun anlamı ise yüzde Allah'ın kelamının 28 ve 32 alametle görünmesidir. $\mathrm{Bu}$ anlayış doğrultusunda Nesîmî, Allah'ın kitabının insan/Hz. Âdem/Fazlullah'ın yüzü olduğunu kanaatindedir:

Ādemüñ vechidür Allāhuñ kitābı uş kitāb

İy kelāmu'llāha münkir huuf min-Allāhic 1-ġayūr (G. 39/3)

"Allah'ın kitabı insanın yüzüdür. İşte kitap. Ey Allah'ın kelamını inkâr eden, Gayur olan Allah'tan kork."

İnsanoğlunun aslının Tanrı olduğunun dile getirildiği dörtlükte otuz ikinin Hakk'ın kelamı olduğu; bütün âlemin aslının Allah olduğu; Âdem'in, yüzü güneş olan bir can olduğu belirtilmektedir:

Hak Te $e^{c} a ̄ a \overline{~ A ̄ d e m o g ̀ l ı ~ o ̈ z i d u ̈ r ~}$

Otuz iki Ḥaḳ kelāmı sözidür

Cümle `ālem bil ki Allāh özidür

Ādem ol cāndur ki güneş yüzidür (T. 42)

“Hak Teâlâ insanoğlunun özüdür. Otuz iki Hakk'ın kelamıdır. Bil ki cümle âlemin özü Allah’tır. Âdem yüzü güneş olan o candır."

Refi'î, “Mümimin kalbi Allah'ın arşıdır.” (Meclisî, C. 55: 39) hadisinden hareketle arşı Hurûfîlik felsefesi çerçevesinde yorumlar. O; müminin kalbi Allah'ın arşı ve evi olduğuna, onda sözden başka, yani 28 ve 32 harften başka bir şey olmadığına göre, Rahman'ın kelime, arşın da Âdem (insan) olduğu görüşündedir (Usluer, 2014:275). İnsanın yüzünde yer alan yedi ümmî ve yedi ebî hat toplamda 14 hat 
etmektedir. Mahalleriyle birlikte 28 sayısına ulaşır. Bu da 28 ilahi harfe tekabül eder. Ayrıca 28 ilahi harf varlığın temelidir. 28 ilahi harf, Allah'ın zatından ayrılmamaktadır. Aşağıdaki beyit bu bilgiler bağlamında okunabilir:

Vech-i Ādem ki ` Arş-1 rahmāndur

Gözlerüñ anda gördi Yezdānı (Tb. 3/2/10)

“Âdem'in yüzü ki Rahman'ın arşıdır. Senin gözlerin orada Tanrı'yı gördü.”

"Sen Allah ile beraber başka bir ilâha ibadet etme. Ondan başka hiçbir ilah yoktur. Onun zatından (vechinden) başka her şey yok olacaktır. Hüküm yalnızca onundur ve kesinlikle ona döndürüleceksiniz." (el-Kasas 28/88). "Kamu fenâ" ifadesiyle yukarıdaki ayette geçen "Onun zatından (vechinden) başka her şey yok olacaktır." ifadesine telmihte bulunulmaktadır. Fazlullah'a göre burada bahis konusu olan insan yüzüdür. Çünkü onun dışında hiçbir mahlûk 32 ilahi kelimenin âlemine sahip değildir. Aynı şekilde Âdem'den başka hiç kimse esmâ-i külle, yani 32 ilahi kelimeye mazhar değildir. İnsan yüzü, 32 ilahi kelimenin makamı olduğundan helak olmayacaktır. İkinci olarak onun yüzünden başka her şeyin helak oluşu, kâinattaki her şeyin "kün" emriyle yaratılmasından dolayıdır. Bunun tek istisnası 32 ilahi kelimedir. Yüz de kün emriyle yaratılmayan tek şey olan bu 32 ilahi kelimenin makamı olduğundan yok olmayacaktır. Üçüncü olarak, ayette her şeyin helak olmasından kastedilen; 32 kelimeye dönmesidir. Ayette yüzün istisna edilmesinin nedeni, onun zaten 32 ilahi kelimenin makamı olmasidır.

"Limeni'l-mülk”, ibaresi “Mülk kimindir?” manasına gelir ve şair, bu ibare ile el-Mü'min 40/16 ayetine işaret etmektedir. Ayetin tamamı şu şekildedir: "O gün onlar ortaya çıkarlar. Onların hiçbir şeyi Allah'a gizli kalmaz. Bugün mülk (hükümranlı) kimindir? Tek olan, her şeyi kudret ve hâkimiyeti altında tutan Allah'ındır.” (el-Mü'min 40/16). Aşağıdaki beyti yukarıdaki bilgiler 1şı̆̆ında yorumlamak mümkündür:

Vech-i ādemden özge cümleye hem

Limeni'l-mülk didi kamu fenā (Tb. 3/7/7)

"Âdem'in yüzünden başka herkese mülk kimindir diye sordu? Her şey geçicidir.”

Hurûfîlere göre, insanın yüzünde bulunan 7 ümmî hattan (saç, iki kaş ve dört kirpik) hatt-1 istiva geçtikten sonra 8 hat belirmektedir. Bu ümmî hatlardan sadece saç hattı, hatt-1 istiva üzerinde yer aldığından ikiye ayrılmakta ve iki hat olarak hesaplanmaktadır. Aynı şekilde yüzde yer alan 7 delikten (iki göz, iki kulak, iki burun ve ağız boşluğu) de istiva hattı geçtikten sonra ağız ikiye bölünür ve 8 delik ortaya çıkar. Bu sekiz hat (Delik de hat olarak kabul edilmektedir.) 4'er unsurdan oluştuğu için 32 hat meydana gelir. Bu 32 hat da esma-i küll olan ve Fazlullah'ın nutkundan gelen 32 harfi karşılamaktadır.

Harfler Allah'ın bir sıfatıdır. Allah'ın kelamı olarak Allah'1 ifade eder. Allah'tan ayrı düşünülmezler. Hurûfîler harflerin mevcudiyetini yaratılmış her şeyde ve kendi varlıklarında (insan varlığında) görürler. Bu şekilde Allah'ın kendilerinde müşahede ettiklerine inanırlar. Aşağıdaki iki beyitte Allah'ın insanın yüzüne 32 ilahi kelime yazdığı, topraktan yarattığı Âdem/Fazlullah ile ihsanda bulunduğu ifade edilmektedir:

Vechüñe yazdı otuz iki ḥurūf

Ḥikmet ile münşīi erkānumuz (G. 189/13)

"Esaslarımızı yapan, hikmet ile senin yüzüne otuz iki harf yazdı." 
Tā bilesin kim ne imiş iy faḳị̣

Ādem-i ḩākỉ ile iḥsānumuz (G. 189/14)

"Ta ki ey fakih, topraktan yaratılan Hz. Âdem ile ihsanımızın ne olduğunu bilesin."

Hurûfîlere göre ilahi kelimelerin tam manasıyla zuhur ettiği yer yüzdür. Yüzde bulunan duyu organları taksim edildiğinde 28 ilahi kelimeye ulaşılır. Bunun anlamı ise insan yüzünde Allah'ın kelamının 28 ve 32 alametle görünmesidir. Beyitte insan yüzündeki 28 ve 32 ilahi kelimenin mevcudiyeti dile getirilmiştir:

Kātib ki yüzi harfini yazdı sī vü düden

İgirmi sekizden

Ol Ādem-i ḩākỉ budur ādem ḩaberidür

Ḳ1 nakş̧-1 ezelde (Müs. 1/2)

"Kâtip, yüzünün harfini 32 ve $28^{\prime}$ den yazd1. Yirmi sekizden (olan) o topraktan yaratılan Âdem/Fazlullah, insanın habercisidir."

Âdem/insan yüzü, üzerinde bulunan hatlar dolayısıyla Hakk'ın sıfatı konumundadır. Bir anlamda 28 ve 32 ilahi harf dolayısıyla Allah'ın tecelligâhıdır:

Vech-i Ādem șıfat-1 Ḥaḳdur çün

Nuṭk-1 Ḥaḳ oldı ḳılur āgāāz (Tb. 3/5/4)

“Âdem'in yüzü Hakk'ın sıfatı olduğu için Hakk'ın sözüdür ve konuşmaya başlar.”

İnsan yüzünün hatlar sebebiyle Hakk'ın sıfatı olduğunu dile getiren Nesîmî, 32 hattın, Allah'ın evliya kulları olduğu beyan eder:

Vech-i Ādem șıfat-1 Ḥaḳ be-yaḳin

Sì vü dü hat ülā'ike'l-ebdāl (Tb. 3/6/10)

“Kesin olarak Âdem'in yüzü Hakk'ın sıfatıdır. 32 hat, Allah'ın evliya kullarıdır."

Âdem'de görülen her alamet (28 ve 32 ilahi kitabet gibi) alamet olarak aslında her insanda zuhur eder. Dolayısıyla Âdem için kabul gören her çıkarım genel anlamda bütün insanlar için de geçerlidir. Tüm varlık insana âşıktır, bu sebepten toprağa secde ederler. Bu aşkın nedeni insanın yüzüdür; çünkü "Allah, insanı kendi sureti ve Rahman sureti üzerine yaratmıştır." Ayrıca Allah'ın zatının kadim sıfatı olan 28 ve 32 ilahi kelimenin hepsi insan yüzünde görülür ve okunur. Şairimiz okuyucularına cevabını bildiği "Bu dokuz havada duran çark (felek) niçin yaratıldı ve Hz. Âdem'in yüzüne bu kadar istekli olmanın sebebi nedir?" sorularını yöneltmekte ve tecahül-i arif sanatı yapmaktadır. Felekler, saygı göstermek için Âdem'in yüzü etrafında dönmektedir. Âdem'in yüzüne istekli olmanın/saygı duymanın sebebi, onun, 28 ve 32 ilahi kelimeyi taşıması hasebiyle Allah'ın tecelli ettiği mahal olmasıdır. Ayrıca insan yüzü ise Allah'ın tecelligâhı olması hasebiyle kıbledir, yani Kâbe'dir:

Bu țoḳuz çarh-1 mu' allak neden oldı tertïb

Ādemüñ șūretine munca țāleb-kār nedür (G. 102/2)

"Bu gökte asılı duran dokuz kat felek niçin yaratıldı? Âdem'in yüzüne bu kadar istekli olmanın sebebi nedir?" 
Nesîmî; Hurûfî bakış açısıyla muhatabından, Âdem'e gelmesini ve Hz. Âdem'in/insan/Fazlullah ne olduğunu bilmesini ister ve Hakk'1n, yüzdeki tecelli ruhu olduğunu belirtir:

Ādeme gel ādemi bil ādemi

$\bar{A}$ demī olanlaruñ budur demi

Bu demüñ zāâtında derdümüñ demi

Ḥaḳ ruhuñ rūḥı durur nedür demi (T. 294)

“Âdem'e gel (insan ol) ve insanın ne olduğunu bil. İnsan olanların işi budur. Benim derdimin sebebi tam da budur. Hak, yüzdeki tecelli rûhudur, başka nedir ki?"

İnsanın yüzünde 32 ilahi kelimeye tekabül eden 32 hat anlayışına aşağıdaki beyitte de yer verilmektedir:

Vech-i Ādemde otuz iki hat

Mūsīye söyledi Enellāh nār (Tb. 3/4/4)

"Hz. Âdem'in yüzünde 32 hat var. Ateş, Hz. Musa'ya "Ben Allah’ım.” dedi."

\section{4. Âdem'in Tanrı Mazharı Olması}

Tüm varlık, zat-1 ilahi ve sıfatları ifade eden harfler sayesinde vardır. İnsan kelime ve kelamın mazharı durumundadır. Kelime de Allah'ın mazharıdır ve böyle olunca ondan ayrı düşünülemez. Kelime, ilahi hat anlamına gelir. Eğer kelime eşyayı kuşatmamış olsaydı, Allah da bilinemezdi. Allah'ın zat ve sıfatından bahsedilemezdi. Bundan dolayı eşya Allah'ın mazharıdır. Âdem'in/Hz. Âdem/insan/Fazlullah mutlak varlıktan olduğunun belirtildiği beyitte Allah'ın yaratma hadisesine ya da yukarıda zikrettiğimiz Âdem'in Allah'ın mazharı olduğu kanaatine işaret olunmaktadır:

Vücūd-1 Muṭlāḳiden oldı Ādem

Risālet ḳapusı Fürkāan degül mi (G. 435/9)

“Âdem mutlak varlıktan (Allah’tan) oldu. Peygamberlik kapısı doğruyu yanlıştan ayırıcı değil mi?"

Aşağıdaki beyitte, Hurûfîlik öğretisi perspektifinde insanın ya da Hz. Âdem'in/Fazlullah'ın Tanrı mazharı olduğu inancı söz konusudur:

Ger inanmazsañ ki Ādem mazharıdur Tañrınuñ

Ḥaḳ te ālānuñ sözinden munca burhān buldum uş (G. 205/10)

“Hz. Âdem'in Tanrı'nın mazharı olduğuna inanmazsan Hak Teâlâ'nın sözünden işte bu kadar delil buldum."

\section{Ayetlerle Âdem}

Âdem isminin geçtiği bazı beyitlerde ayetlere yer verilir. Hurûfîlerin insana verdikleri önem, elbette İslam'dan kaynaklanır. Kur'an'da "Biz insanı en güzel biçimde yarattık." (et-Tîn 95/4) denir. İnsan eşref-i mahlûkattır ve bütün İslami kaynaklarda mahlûkatın en üst seviyesinde yer alır. Hurûfîler tüm bu kaynaklardan istifade ederek insanı felsefelerinin temeline koymuşlar; harfler ile insan vücudu arasında kurdukları eşdeşlik üzerinden insanın mükemmelliğini göstermeye çalışmışlardır. Âdem'in hilkatini inkâr ederek onun yüzünde 32 kelimeyi okumayanlar Allah'ın yüzünün temaşasından mahrum olur. Yani onlar nefislerini bilmeyip hayvan sıfatıyla sıfatlananlardır. Ayrıca bunlar insanın yüzündeki cenneti göremeyip cehennemde kalanlardır: 
Ger itmez iseñ aḥsen-i taḳvīme sücūdı

Ādem kimi bil cismüñe sen cān olamazsan (G. 342/9)

"Eğer "ahsen-i takvim"e secde itmez isen Hz. Âdem gibi bil bedenine sen can olamazsın."

"Ve leķad kerrem beni Ādem” ibaresi el-İsrâ 17/70'te geçer ve “And olsun, biz insanoğlunu şerefli kıldık." manasına gelir. Dörtlükte on sekiz bin âlemin sırrının Hz. Âdem/Fazlullah/insan olduğu beyan edilir:

‘ ̇̇sīnüñ aṣlın bilen Meryemdedür

Hem Süleymān hịkmeti hāatemdedür

On sekiz miñ `ālemüñ sırrın bilen

Ve leḳad kerrem benī Ādemdedür (T. 81)

“Hz. İsa'nın aslını bilen Hz. Meryem'dedir. Hz. Süleyman'ın hikmeti mühürdedir. On sekiz bin âlemin sırrını bilen "And olsun, biz insanoğlunu şerefli kıldık." -ayetinden- anlaşıldığı üzere insanoğlundadır.."6

\section{Esmâ-i Kül}

Hurûfîler, esmâ-i kül hakkında da yorumda bulunmuşlardır. Allah'ın, Âdem'i yarattıktan sonra, melek vasıtası olmaksızın ona öğrettiği esmâ-i kül, yani isimlerin tamamılla kastedilen isimler, esmâ-i hüsnâ (el-A'râf 7/180), esmâ-i zat ve esmâ-i sıfat, tüm mevcudatın isimlerini, tüm semâvî kitapları ve tüm ilimleri kapsar. Buna peygamberlerin, meleklerin sözleri de dâhildir. Bütün isimler, tüm isimlerin aslı olan ve tüm isimlerin kendisinden meydana geldiği 32 ilahi kelimedir. Hz. Âdem'e öğretilen esmai küllü Hurûfîler, 28 ve 32 ilahi harfin tecellisi olan ve insan yüzünde bulunan 28 ve 32 hat olarak yorumlamışlardır. Esma-i küllü bilmesi dolayısıyla melekler Hz. Âdem'e secde etmişlerdi.

Melekler, Âdem yaratılmadan önce isimlerden bazılarını bilmekteydi. Yani anlayıp konuştukları isimler sınırlı sayıdaydı. Nitekim melekler de, kendilerine Allah'ın öğrettiğinden başka, bir bilgiye sahip olmadıklarını söylemişlerdir. Bu isimler Allah'ı tesbih, hamd ve takdis ettikleri kelimelerdir. Aşağıdaki beyitte meleklerin Âdem'den esmâ-i küllü talim etmesi bahis konusudur:

Ādem-i hākīiden esmā ögrenenlerdür melek

Dīvüñ aṣlı od idi ögrenmedi esmāmuzı (G. 438/2)

“Melekler, topraktan meydana gelmiş Âdem'den isimleri öğrenmişlerdir. Şeytan'ın aslı ateşten idi, isimlerimizi öğrenmedi."

“'Alleme'l-esmâ", ibaresi Bakara Suresi, 31. ayette geçer. Burada Allah'1n Hz. Âdem'e bütün isimleri öğrettiği ifade edilir. Hurûfîler bu ayetle ilgili tevilde bulunur. 32 ayetten kasit, yüzde bulunan 32 hattır. Esma-i külden murat ise, 28 ve 32 ilahi harfin tecellisi olan ve insan yüzünde bulunan 28 ve 32 hattır. Dörtlükteki "sırr-1 esmâ" ifadesini bu bağlamda anlamlandırabiliriz:

Cevher-i ferd ādemüñ kānındadur

Küntü kenzen Ādemüñ şānındadur

Gerçi Şeyțān ādemün ḳanındadur

Sırr-1 esmā Ādemüñ cānındadur (T. 43)

\footnotetext{
6 “Ayetlerle Âdem" başlı̆̆ı altında örnek verilenlerden başka ayetlerde de Âdem ismine rastlarız. Ancak bu ayetleri farklı maddelerde ele aldığımızdan tekrara düşmemek için burada ayrıca bahis konusu yapmadık.
} 
"Eşi olmayan cevher Âdem'in madenindedir. "Küntü kenzen” Âdem'in şanında gelmiştir. Her ne kadar şeytan, Âdem'in kanında olsa da isimlerin sırrı Âdem'in canında mevcuttur."

\section{7. Âdem ve Hz. Muhammed}

Aşağıdaki beyitte Hz. Âdem'in topraktan yaratıldığı gerçeğine işaret vardır. Ayrıca, "Ben Allah katında kesin olarak peygamberlerin sonuncusu olarak yazıldım. Oysa Âdem henüz kendi çamurunda (balçığında) bulunuyordu." mevzu hadisine telmih vardır (Ünal, 2011: 69). Hz. Muhammed'in meleklere nebilik yaparken, Âdem'in su ve çamur arasında olması, Âdem-i hakiki, yani Fazlullah'ın, hadiste mâ ve tîn (su ve çamur) biçiminde özetlenen 4 unsur vasıtasıyla beşerin hilkatini açıklamasına delalet eder. Yani sıfat-1 Fazliyye olan 32 ilahi kelimenin 4 unsur nedeniyle aşikâr olmasıdır. Bu dört unsur sebebiyle insanda harflerin tecellisi zuhur edip 32 kelime görülebilmiştir. Fazlullah-1 Hurûfí'ye göre bu hadiste Hz. Âdem yaratılmadan önce Hz. Muhammed'in meleklere peygamberlik yaptığı ifade edilmektedir. Hurûfîlere göre bu hadiste anlatılmak istenen Hz. Muhammed'in 28 harfinin veya 28 hattının, Hz. Âdem'in 32 harfine/hattına olan önceliğidir. Hadiste, Hz. Muhammed'in önceliğine yapılan vurgu, onun mükemmelliğine değil, Hz. Muhammed'in hakikati olan 28 kelimenin Âdem'in hakikati olan 32 kelimeden daha önce zuhur etmesinedir. Bu durum, Hz. Muhammed'in Fazlullah'tan önce gelmesiyle de açılklanabilir. Hz. Peygamber'den sonra gelmiş olan Fazlullah da Âdem-i hakiki, yani gerçek Âdem'dir. Nesîmî’nin beyti Hz. Peygamber için kaleme alınmış bir övgü olarak yorumlanabileceği gibi, yukarıdaki bilgiler dâhilinde de değerlendirilebilir:

Sensen ol nūrı ki Ādem beyn-i mā-i ṭ̂yn iken

Ol zemān ebnā ḳ1lurduñ cümleye sensen binā (G. 6/5) sensin."

"Âdem, su ile çamur arasındayken, sen bir nur idin. Herkes senin soyundur. Herkesin başı

Bir hadiste Hz. Peygamber, Âdem'in kıyamet gününde sancağının altında olacağını ifade etmiştir (Meclisî, C. 39: 213). Hurûfîler bu hadisi kendi öğretileri çerçevesinde teville açıklama yoluna gitmişlerdir. Bu hadiste sancak (لو (لو) ibaresi, Hz. Muhammed'in konuşmasındaki 28 kelimeden kinayedir. Âdem'in onun sancağının altında oluşu da, Âdem'in nutkundaki 32 kelimenin, 28 kelimeden ortaya çıkmasına işaret eder.

Bir başka yorumda hadiste geçen "sancağım" anlamına gelen "livâ̂̂" (لوايى) kelimesinin eczasından 14 harf (لام واو الف الف يى) ortaya çıkar. Bu da Âdem'in yüzündeki 14 hatta denk gelmektedir, mahalleriyle birlikte 28 sayısı elde edilir. Bununla birlikte livâî'nin eczasındaki 4 nokta da Âdem'in

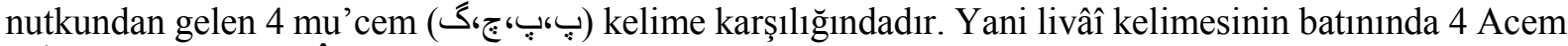
(ب) harfiyle Âdem (Fazlullah) gelmiştir. Nesîmî, beyti bu bilgiler çerçevesinde tesis etmiştir:

Gel imdi Ahmedüñ sırrın te` akḳul ḳ1 eyā ‘āḳ1

Ki der-taḩt-1 livā Ādem didi bu ma' nīden Yezdān (G. 311/9)

"Ey akıllı kimse! Gel, şimdi Ahmed'in sırrını düşün. Allah, bu yüzden Âdem bu sancağın altında, dedi."

\section{8. Âdem ve Vahdet-i Vücut}

Dünyadaki her şey, harflerin bir mazharıdır ve harflerin hükümlerine tabidir. Sözgelimi, insanın içerisinde iyilik, kötülük; hareket, durgunluk gibi herhangi bir anlama gelecek biçimde harfler bir araya gelmiyorsa, bahis konusu eylemi insan yapamaz. Çeşitli anlamlara gelen harflerin bu terkibi insan kalbinde istek dışı bir şekilde tecelli eder ve görünür. Bu tecellinin kaynağı ise "Mütekellim-i hakiki" olan Allah'tır. Bu bilgiler doğrultusunda Nesîmî muhatabından ikilikten geçip elif harfi gibi tek olmasını, Âdem'de Hakk'1 görüp ona secde etmesini ister: 
Geç ikilikden elif tek vāhịid ol

Haḳḳı gör Ādemde Haḳka sācid ol

Gel fenānuñ baḥrına düş ḩālid ol

Ka' beyi tanı vü Lāta 'abid ol (T. 187)

“İkilikten geçip elif harfi gibi tek ol. Âdem'de Hakk'1 görüp Hakk'a secde et. Gel, yokluğun denizine dal, sonsuz, ebedi ol. Kâbe'yi tanı ve Lata kulluk et."

Hurûfîler, zat-1 ilahi' yi harflerle tanımlarlar. Zatı bütün mevcudatta harfler vasıtasıyla müşahede ederler. Hurûfîlik telakkisine göre, her şeyin hakikati "bir"dir (her şey birdendir) ve bu "bir"in mazharları çoktur. Her bir mazhar da isme veya sıfata aynalık yapar vaziyettedir. O isim ve sıfatlara "hakikat-i eşya" adı verilir ve bunların sahibi "Zat-1 Mutlak"tır. "Zat-1 Mutlak" ise hakikatlerin hakikatidir. Onun ilk tecellisi ve ilk sureti ezelden beri konuştuğu 32 harftir. Her mazharın zuhuru, Zat olan bir harften olması sebebiyledir. "Allah her şeyi kuşatmıştır." (Fussilet 41/54) ayetinde geçtiği gibi Allah kelam-1 kadimiyle yani 32 ilahi kelime aracılığıyla her şeye muhit olmuştur. Allah, varlığ varlıkların ismiyle kuşatmıştır. Bu öğretiyi benimseyen Nesîmî, vahdetin şehrinde gezinmektedir:

Vaḥdetüñ şehrinde seyrān eylerem

Men seni cismümde hayrān eylerem

Gencümi Ādemde pinhān eylerem

Ādemi hem Ḥaḳ hem insān eylerem (T. 219)

"Vahdetin şehrinde geziyorum. Ben seni bedenimde hayran eylerim. Hazinemi Âdem'de gizlerim. Âdem'i hem Hak hem insan eylerim."

Miraçla ilgili hadiste zikredildiği üzere Hz. Peygamber birinci kat gökte Hz. Âdem ile karşılaşmış ve selamlaşmıştır. Hz. Peygamber'in birinci kat gökte Âdem'i görmesinin nedenlerinden biri onu bilmeden Allah'ın bilinemeyeceğine işaret etmektir. İnsan, Âdem'i bilmeden kendi nefsini bilemez ve kendini bilmeyince de Allah'1 bilmenin imkânı yoktur.

Allah'ın zatı tüm mevcudatı kelamıla muhit olduğu için insan mevcudatta ve kendinde kelimeleri müşahede ettiği zaman Allah'1 müşahede etmiş olacaktır. Böylece tüm varlıkta Allah'tan başka bir şey görmeyecektir. Aşağıdaki beyit de vahdet-i vücut anlayışı minvalinde yorumlanmalıdır:

Her kim seni bildi Hakkı bildi

Her kim Haḳı bildi Ādem oldı (Tb. 2/5/9)

“Her kim seni bildi, Allah'ı bilmiş oldu. Her kim Allah'ı bildi, Hz. Âdem/insan oldu.”

Nesîmî; Hz. Âdem'in, Havva'nın, meleklerin, hurilerin, cennet ehlinin hizmetiyle görevlendirilen gençlerin, insanın; Kevser' in, Tuba ağacının, Rıdvan'ın, cennet ve yüzün vahdet şarabı veya elest meclisinde sunulan şarap ile sarhoş olduğu iddiasındadır:

Ādem ü Hạvāa melā'ik ḥūr u g̣̀lmān u beşer

Kevșer ü Ṭūbā vü Riḍvān cennet ü dīiār mest (G. 22/13)

"Hz. Âdem, Havva, melekler, huriler, cennet ehlinin hizmetiyle görevlendirilen gençler, insan; Kevser, tuba, Rıdvan, cennet ve yüz sarhoştur."

Âdem isminin geçtiği aşağıdaki beyitlerde de vahdet-i vücut anlayışının dile getirildiği söylenebilir: 
Hem uran hem nefhayı hem rūḥ̂- Ādem hem türāb

Hem ḳıyāmet șūrıyam hem mahşerüñ nāḳūrıyam (G. 241/20)

"Hem üfleyen hem Hz. Âdem'in ruhu hem toprak. Hem kıyametin suruyum hem mahşerin düdüğüyüm."

Hem menem ins ü melek hem Ādem-i Hुāki ilen

Bulmışam hem 'Arş-1 Raḥmān cümle oldum kā'ināt (G. 26/9)

"Hem insan ve melek benim hem de topraktan yaratılan Hz. Âdem ile Rahman'ın arşını bulup tamamen kâinat oldum."

\section{9. Âdem ve Diğer Peygamberler}

Fazlullah'ın kelime nazariyesi esas olarak, İbn Arabî’nin görüşünün iki yönüne dayanır. Bunlardan birincisi, bütün peygamberlerin kelime olarak yorumlanmasıdır. Bunu yaparken de başlangıç noktası Hz. İsa'dır. Hz. İsa'nın Kur'an'da geçtiği üzere (en-Nisâ 4/171) kelime ve ruh olmasını bütün peygamberleri de bunun içine dâhil ederek tevilde bulunur. Ona göre peygamberler kelimenin farklı farklı tezahürleridir. Peygamberlerin açıkladığı tüm hakikatlerin kaynağı da kelimedir. Fakat Fazlullah, bu peygamberler arasında en câmî olanının hangisi olduğu konusunda İbn Arabî'den farklı bir kanaate sahiptir. İbn Arabî, bunun tartıșmasız bir şekilde Hz. Muhammed olduğu görüșündedir. Fazlullah ise Hz. Âdem olduğunu iddia eder. Bunu ispatlamak için de Hz. Muhammed ile Hz. Âdem arasında karşılaştırmalar yapma yoluna gider. Ona göre, Hz. Âdem birçok özelliğinden dolayı Hz. Muhammed'in önüne geçer, bütün evliya ve enbiyaları câmî bir makamda yer alır (Ball1, 2013:170-171). Fazlullah, Mesih ve Mehdi olduğunu, ispat etme gayretindedir. Onun takipçileri ise buradan hareket ederek Mesih ve Mehdi hakkında bilinen rivayetleri kendilerince yorumlarlar. Böylece onun Mesih ve Mehdi olduğu görüşünü pekiştirmeye çalışırlar (Ballı, 2013:141). Aşağıdaki beyit bu bilgiler ışığında yorumlanabilir:

'īsīi pāk ü Ahmed ü Ādem

Mehdīi șāḥib-i zamāndur söz (G. 179/12)

"Söz, zamanın sahibi Mehdi, pak olan Hz. İsa, Hz. Muhammed ve Hz. Âdem'dir."

\section{Hz. Âdem'in Cennetten Çıkarılması}

Şathiye kabilinden olan beyitte Hz. Âdem ile Havva'nın yasak meyveyi yemesi dolayısıyla günah işlemeleri hadisesine işaret olunmaktadır:

Bu dā' ì ḳullaruñ cürmi cihānda şimdi mi ḳaldı

Güneh evvelde ḳalmışdur bize Ḥavvā vü Ādemden (G. 347/16)

"Bu dua eden kulların günahı dünyada şimdi mi meydana geldi? Günah geçmişte bize Havva ile Hz. Âdem'den geçmiştir."

Hz. Âdem, cennetten yeryüzüne indirildiğinde karnı acıktı. Rabbinden yemek istedi. Allah, Cebrail ile ona yedi buğday tanesi gönderdi. Cebrail'den buğdayı ekmeyi, biçmeyi ve toplamayı öğrendi (Aydemir, 1992: 34-35). Aşağıdaki beyitte sevgilinin yüzündeki misk kokulu tane (ben) buğdaya benzetilmiştir. Hz. Âdem'in cennetten uzaklaştırılması, sevgilinin yüzündeki beni görmesi hayali sebebine bağlanmış ve böylece hüsn-i talil sanatı yapılmıştır:

Ādemi cennetden rag் eyleyen çün bog̀dadur

Neylesün çün kim yüzüñde gördi müşkīn dāneyi (G. 406/6) 

gördü."

“Âdem'i cennetten uzaklaştıran buğdaydır. Ne yapsın, senin yüzünde misk kokulu taneyi

\section{1. Âdem ve "Küntü Kenz"}

Hz. Âdem'in isminin geçtiği iki şiirde "küntü kenz" ibaresinin yer aldığını görmekteyiz. "Küntü kenz" ise "Ben gizli bir hazine idim. Bilinmeyi istedim ve bilinmek için halkı yarattım." (Yılmaz, 1992: 91) anlamındaki hadis-i şerifin baş kısmıdır. Aşağıya kaydettiğimiz beyitte bu hadisin incisinin Âdem olduğu söylenmektedir:

'Āşı̣uñ seyrānı ol 'ālemdedür

Görmeyen şol ' ālemi mātemdedür

Küntü kenzüñ gevheri Ādemdedür

Ādem ol meydür ki cām-1 Cemdedür (T. 87)

“Aşı̆̆ın seyranı o âlemdedir. O âlemi görmeyen matemdedir. "Küntü kenz"in incisi Âdem'dedir. Âdem, Cem'in kadehinin şarabıdır." düşünür:

Nesîmî; "küntü kenz” (gizli hazine) bağlamında yaratılmanın Âdem’in şanında gerçekleştiğini

Cevher-i ferd ādemüñ kānındadur

Küntü kenzen Ādemüñ şānındadur

Gerçi Şeyțān ādemün ḳanındadur

Sırr-1 esmā Ādemüñ cānındadur (T. 43)

"Eşi olmayan cevher Âdem'in madenindedir. "Küntü kenzen” Âdem'in şanında gelmiştir. Her ne kadar şeytan, Âdem'in kanında olsa da isimlerin sırrı Âdem'in canında mevcuttur."

\section{Hz. Âdem'in Yaratılması ve Önemi}

Bir kutsi hadiste “Âdem'in çamurunu iki elimle kırk sabah yoğurdum.” buyrulmaktadır. Hurûfîler bu hadisi harfler ve hatlar üzerinden yorumlamışlardır. Bu tevillerden birini örnek olması hasebiyle kaydediyoruz: Hadis (خمرت طينه ادم بيدى اربعين صباحا) Hz. Muhammed'in nutkundaki harf sayısınca 28 kelime ve 20 noktadan meydana gelir. Toplamı Âdem'in çamurunun yoğrulduğu 40 gün ile onun yüzünde görünen 8 hat hizasındadır. Hurûfî yorumlardan birisinde 40 günün, Fazlullah'ın (فضل) isminde görünmesi sebebiyle Âdem'in çamurunun yoğrulmasından kastın, Fazlullah'ın zuhuru olduğu dile getirilmiştir:

Beyitteki "Kâf ve nûn" ile Allah'ın kün (ol) emrine telmih vardır. Hurûfîler harfleri mevcudatın temeli olarak görürler. Birçok filozof gibi onlar da "Onun emri, bir şeyi dileyince ona sadece "ol" demesidir. O da hemen oluverir." (Yâsîn 36/82) ayetini esas alırlar. Nitekim yaratılış harflerden oluşan kün (كن) yani "ol” emriyle gerçekleşir:

Kāf ile nūndan yaratdı ' ālemi

Erba‘ in günde yog̉urmış Ādemi

Dem bu demdür dem bu dem bil bu demi

Ādeme urdı bu demden Haḳ demi (T. 295)

"Kâf ile nûndan (Kün) âlemi yarattı. Kırk günde Âdem'i yoğurmuş. Zaman bu zamandır zaman bu zaman bu zamanı bil. Hak bu nefesten Âdem'e nefesi üfledi.” 
Fazlullah'ın kurduğu felsefenin iskeletini, özelde Hz. Âdem'in genelde ise insanın önemi oluşturur. Bu felsefe, Hz. Âdem'in kendinden başka varlıklarla karşılaştırılarak veya bazen de onlarla aynileştirilerek inşa edilir. Ortaya konulan görüşlerin merkezinde daima Hz. Âdem vardır. Bundan dolayı kâinat, Hz. Âdem ve diğer varlıklar olmak üzere ikiye ayrılarak ele alınır. Bununla birlikte Hz. Âdem ve dünya arasındaki aynileşme daha Hz. Âdem'in yaratılması esnasında ortaya çıkar. Çünkü Fazlullah, Allah'ın, Hz. Âdem'i, kendi eliyle yeryüzünden aldığı bir avuç toprakla yarattığ1 kanaatindedir. Buna delil olarak, "Allah, Âdem'in yüzünü Kâbe toprăgından, göğsünü ve sırtını Beytü'lMakdis toprağından, săg elini doğu topră̆ından, sol elini ve ayaklarını batı toprağından, baldırlarını Yemen toprağından, bacaklarını Hicaz toprağından yaratmıştır." (Âlûsî, C. 9, t.y: 111) rivayetini nakleder. Böylece Hz. Âdem'in bil-kuvve bütün yeryüzünden yaratılmış olduğunu ileri sürer. $\mathrm{Bu}$ yaratma sırasında yıldızlar ve felekler de, saygı nişanesi olarak, Hz. Âdem'in yüzü için etrafında dönmeye başlamışlar ve Allah da onu yarattığ toprağ 40 sabah boyunca mayalamıştır. Bu işlemden sonra kendi kelamının göstergesi olarak, onun yüzüne 28 ve 32 kelime-i ilahiyi kendi kudret kalemiyle yazmıştır. Daha sonra ise onu 360 ekleme ayırmış, üzerine et ve deri giydirmiştir (Ballı, 2013:99-100). Aşağıdaki beyit bu minval üzere tertip edilmiştir:

Her ne yirde gökde var Ādemde var

Her ki yılda ayda var Ādemde var

Ne ki elde yüzde var ḳademde var

Bu sözi fehm itmeyen ādem davar (T. 57)

"Yerde ve gökte her ne varsa Âdem'de vardır. Yılda ve ayda ne varsa Âdem'de vardır. Elde ve yüzde ne varsa ayakta vardır. Bu sözü anlamayan adam davardır."

Hz. Âdem'in ve insanın sırrını bilenler on sekiz bin âlemin sembolünü (rumuzunu) bilmiştir. On sekiz bin âlemin işareti Hz. Âdem'in yaratılmasında yatmaktadır. Âdem/Hz. Âdem/insan/Fazlullah, Allah'ın tecellisinin mazharıdır. Bu beyitle ilgili şöyle bir yorum da yapılabilir. Fazlullah, "Allah" isminin ism-i azam olduğunu beyan eder. Zira Allah, Âdem'i kendi sureti ve Rahman sureti üzerine yaratmıştır. Bu açıdan bakıldığında Âdem, Allah'ın ism-i azamıdır. Diğer taraftan, "İster 'Allah' deyin, ister 'Rahman' deyin, nasıl çağırırsanız çağırın. En güzel isimler onundur." (el-İsrâ 17/110) ayetinden hareket edildiğinde Âdem, Rahman sureti üzerine yaratıldığı için tüm ilahi isimlerin işaretlerini de bünyesinde barındırır. Ayrıca Fazlullah, Âdem'in ism-i azamın mazharı olduğunu da dile getirir. Bir başka yerde ise Âdem'in yüzünün, Allah'ın isminin veya ism-i azamın kendisinden zuhur ettiği 32 ilahi kelimenin alametlerini bulundurması sebebiyle, ism-i azam olduğunu açıklar. İsm-i azam on sekiz bin âlemi kuşatmıştır. Bu nedenle Âdem'in Hz. Adem'in/insan/Fazlullah'ın sırrını bilenler on sekiz bin âlemin rumuzunu bilecektir:

Ādemüñ sırrın bilenler ādemüñ

Bildi remzin on sekiz miñ ' ālemüñ (Mes. 3/147)

“Âdem'in ve insanın sırrını bilenler on sekiz bin âlemin sembolünü (rumuzunu) bildi."

Aşağıdaki beyti de yapılan açıklamalar çerçevesinde düşünebiliriz:

Ohıdı bir İsm-i a' ẓam ki vücūda geldi Ādem

Ḳoyuban adumı Ādem şu bu gün cihāna geldüm (G. 293/3)

“İsm-i azamı okuyunca Âdem yaratıldı. Adımı Âdem koyarak işte bugün dünyaya geldim.” 


\section{Sonuc}

Nesîmî Divanı'nda Hz. Âdem'le ilgili şiirlerden elde edilen bulgulardan hareketle varılan sonuçlar şunlardır:

1) Hurûfîler Âdem ismi ile insan, Hz. Âdem ve Fazlullah-1 Hurûfî’yi kastetmiştir. Nesîmî de Âdem lafzı ile bu üç ismi karşılayacak beyitler söylemiştir.

2) Divan'da Hz. Âdem ile ilgili beyitlerde şeytanın ona secde etmemesi hadisesi bilhassa konu edilmektedir. Kimi beyitlerde Âdem'e secde etmeyenler şeytan olarak vasıflandırılmıştır.

3) Bazı beyitlerde ise Âdem'e secde edilmesinden bahsedilir.

4) Kimi beyitlerde özellikle Âdem'in yüzü söz konusudur. Bu beyitlerde Âdem'in yüzünün Hakk'ın sıfatı olduğu ve Rahman'ın Arş'ı olduğu, Âdem'in yüzünden başkasının yok olacağı, Âdem'in yüzünde 32 hattın bulunduğu belirtilir.

5) Âdem'in Tanrı mazharı olduğu ve Allah'ın Âdem'de tecelli ettiği beyan edilmiştir.

6) Nesîmî, Âdem dolayısıyla Kuran'da "Biz insanı en güzel biçimde yarattık." (et-Tîn 95/4) ayetinde geçen, "en iyi, en güzel kıvam" manasına gelen ve "insan" anlamını karşılayan "ahsen-i takvîm"e beyitte yer vererek insanın önemine işaret eder.

7) Âdem'i konu edinen beyitlerde ona Allah tarafından öğretilen esmâ-i kül (tüm isimler) Hurûfî bakış açısıyla ele alınmıştır. Hurûfîler, Hz. Âdem'e Allah tarafından talim edilen “esmâ-i kül”ü 28 ve 32 ilahi harfin tecellisi olan ve insan yüzünde bulunan 28 ve 32 hat olarak tevil etmişlerdir. Hz. Âdem, esmâ-i küllü bildiği için melekler ona secde etmiştir.

8) İki hadis bağlamında Âdem ile Hz. Muhammed'e yer verilmiştir. Bu hadisler Hurûfîlik öğretisi çerçevesinde beyitlerde yer bulmuştur.

9) Âdem ile ilgili bazı beyitlerde vahdet-i vücut anlayışının dile getirildiği görülür.

10) Tek bir beyitte Âdem ismi ile birlikte Ahmed (Hz. Peygamber), Hz. İsa ve Mesih adlarına yer verilmiş̧ir. "Söz" ile kastedilen varlığın adı geçen peygamberler olduğu iddia edilmiştir.

11) Şathiye kabilinden sayabileceğimiz bir beyitte Hz. Âdem ile Havva'nın yasak meyveyi yemeleri dolayısıyla günah işlemeleri hadisesine telmih vardır. Hz. Âdem Divan'da çoğunlukla Hurûfî öğretisi perspektifinden ele alınsa da bir başka beyitte günah işleyip cennetten çıkarılması hadisesi sanatkârane bir şekilde ele alınır. Cennetten uzaklaştırılmasına sebep olarak sevgilinin yüzündeki beni görmesi gösterilir. Böylece hüsn-i talil sanatı yapılır. Bu beytin sanat yapmak amacıyla kaleme alındığı söylenebilir.

12) İki tuyuğda "küntü kenz" hadisi Âdem ismi ile birlikte geçer. Dörtlüklerde bu hadis ile ilgili olarak Âdem'in önemi Hurûfillik öğretisi çerçevesinde vurgulanır.

13) Hz. Âdem'in yaratılması Hurûfî bakış açısıyla tek bir tuyuğda işlenmiştir. Bu şiir de Hurûfílik perspektifinden değerlendirilebilir.

\section{KAYNAKÇA}

Allâme Meclisî, Bihâru'l-Envâr, Müessese El-Vefâ, Beyrut, k. 1404.

Âlûsî, Ebu's-Senâ Şihâbüddîn Mahmûd b. Abdillah el-Hüseynî, Rûhu'l-Meânî fì Tefsîri'l-Kur'âni'lAzîm ve's-Seb 'i'l-Mesânî, Dâru İhyâi't-Türâsi'l-Arabî, Beyrut.

Ayan, Hüseyin (2002). Nesîmî, Hayatı, Edebî Kişiliği, Eserleri ve Türkçe Divanının Tenkitli Metni 1-2, Ankara: TDK Yay. 
Aydemir, Abdullah (1992). İslâmî Kaynaklara Göre Peygamberler, Ankara: Türkiye Diyanet Vakfı Yay.

Bilgin, Azmi (2007). "Nesîmî”, DİA C. 33, İstanbul: Türkiye Diyanet Vakfı Yay., s. 3-5.

Karabey, Turgut (2017). Nesimi -Hayatı, sanatı, eserleri, Bazı Şiirlerinin Açılamaları, Ankara: Akçağ Yay.

Şenödeyici, Özer (2015). Nesîmî ve Hurûfîlik Kitabı. İstanbul: Kesit Yay.

Usluer, Fatih (2009). "Nesîmî Şiirleri Şerhlerinde Yapılan Yanlışlıklar”, Turkish Studies, Vol 5/2 (Winter), s. 1072-1091.

Usluer, Fatih (2014). Hurufilik İlk Elden Kaynaklarla Doğuşundan İtibaren, İstanbul: Kabalc1 Yay.

Ünal, Harun (2011), El-Ehadis'ul-mevdua Mevzuat (Mevzu Hadisler), İstanbul, Helal Denetim Merkezi Kültür Yay.

Yılmaz, Mehmet (1992), Edebiyatımızda İslamî Kaynaklı Sözler (Ansiklopedik Sözlük), İstanbul: Enderun Yay. 